Article

\title{
How Does Improve Farmers' Attitudes toward Ecosystem Services to Support Sustainable Development of Agriculture? Based on Environmental Kuznets Curve Theory
}

\author{
Yaofeng Yang ${ }^{1,2} \oplus$, Yajuan Chen ${ }^{1,2,3, *}$, Zhenrong $\mathrm{Yu}^{3}$, Pengyao $\mathrm{Li}^{3}$ and Xuedong $\mathrm{Li}^{3,4}$ \\ 1 School of Economics and Management, Inner Mongolia Normal University, Hohhot 010022, China; \\ yyfnmg@163.com \\ 2 College of Life Science and Technology, Inner Mongolia Normal University, Hohhot 010022, China \\ 3 College of Resources and Environmental Sciences, China Agricultural University, Beijing 100193, China; \\ yuzhr@cau.edu.cn (Z.Y.); lipengyao@cau.edu.cn (P.L.); 24171@sdjz.edu.cn (X.L.) \\ 4 School of Architecture and Urban Planning, Shandong Jianzhu University, Jinan 250101, China \\ * Correspondence: yaya576@126.com; Tel.: +86-471-4393-323
}

Received: 19 September 2020; Accepted: 13 October 2020; Published: 19 October 2020

check for updates

\begin{abstract}
Agroecosystems are complex socio-ecological systems that are managed by farmers to achieve desired outcomes, including economic income and environmental benefits contributed by ecosystem services (ES). Therefore, understanding farmers' attitudes for ES will provide references for targeted agricultural environment management, which is critical to achieving the sustainable development of agriculture. The aim of this study is to identify the attitudes of farmers regarding ES, and to test whether and how annual household income and social demographic characteristics affect farmers' attitudes toward ES. Using face-to-face interviews to collect data and the hypothesis of environmental Kuznets curve (EKC) to provide an analytical framework, the results reveal that, in general, the perceptions of farmers' attitudes on ES are highly complex, caused by characteristics of the farmers. Furthermore, the inflection points of the U-shaped curves, where priorities change from increasing income to paying more attention to waste assimilation and biological pest control, are identified at 17,091 and $25,071 \mathrm{RMB}$, respectively. Initiatives that aim to achieve sustainable agricultural development by strengthening ES provisions should be sensitive to farmers'perceptions. Therefore, it is necessary to strengthen farmers' educational attainment, concentrate fragmented cultivation area and create reasonable incentives for preserving and restoring of ES and increasing farmers' income together, which then can enhance the positive outcomes from income growth.
\end{abstract}

Keywords: environmental Kuznets curve; annual household income; social demographic characteristics; ecosystem services; payments for ecosystem services (PES) schemes; incentive mechanism

\section{Introduction}

Human food consumption, as well as feed and fiber production and use, has already placed increasing pressure on the environment [1,2]. The nexus of environment-economy is a prominent issue in global sustainable development, particularly for exploring a conservation strategy in the agroecosystems that comprise roughly half of the global land surface [3,4]. On the one hand, agroecosystems have been considered primarily as sources of provisioning services (such as food, feed and fiber) which are important means of increasing the income of farm households $[5,6]$; on the other hand, more recently their contributions to other types of services have been recognized, such as regulation of soil and water quality, carbon sequestration, support for biodiversity and cultural services, 
as a result of society's demand for growing environmental quality $[1,7,8]$. Indeed, linkages between economically critical provisioning services and environmentally sustaining other types of services are proven to be not only trade-offs but also synergies $[9,10]$. For example, traditional agriculture practices support provisioning services availability by abandoning other types of services and replacing them with external inputs, which in the longer term can offset the productivity of agroecosystems [11]. However, there is increasing evidence that appropriate management in agroecosystems may be a successful strategy to support productivity of nature's services while improving environmental sustainability of ecosystems $[10,12,13]$.

Focusing on the relationships between agricultural production and various ecosystem services (ES) would be helpful in prioritizing which services are most important to manage agroecosystems sustainably. Over recent decades, the complex connectedness among different ES have been explored to better aid in managing agroecosystems. There is evidence that the delivery of regulating services is central to transform trade-offs into synergies among ES; furthermore, supporting services can enhance the delivery of multiple services to maximize synergies among ES [10]. Manure and crop residue through waste assimilation could be utilized in agroecosystems mainly for improving the soil physical and chemical properties and as nutrient sources for growing crops [14,15]. Insect pollination supports production in $75 \%$ of globally important crops; moreover, pollination displays synergistic, compensatory or additive effects with other factors contributing to yield, such as nutrient availability and control of pests [13].Increasing the potential for biological pest control by conservation efforts and disturbance mitigation could provide broader co-benefits for agroecosystem [16].Water regulation could go hand-in-hand with increased yields through consuming rainfall, increasing soil moisture and keeping groundwater stability, reducing vulnerability to waterlogging and salinization in agroecosystems [17]. Maintenance of natural genetic diversity plays a significant role in the ES cascade, since increasing diversity has shown to be useful in pest and disease management and has the potential to enhance pollination services and soil processes in specific situations [18]. However, one of the inherent difficulties of managing ecosystem services is that the individuals who control the supply of such services, such as farmers and other land managers, may strongly influence the delivery of services [1]. Therefore, it is crucial to know the opinions of farmers who manage ES on their land.

Farmers' attitude could positively affect their behavior, therefore it is meaningful to understand the trajectories of farmers' attitude changes and continue to shape the trajectories. The "Kuznets curve" describes an inverted U-shape relationship between income inequality and economic development [19]. The Kuznets curve has also been extended to describe changes in pollution or other impacts that are believed to occur during socioeconomic development; this curve is referred to as the "environmental Kuznets curve" (EKC) [20-22]. Agrarian economies tend to exploit more natural resources and ES [23]. Therefore, the analysis of environment-economy about agroecosystem differs from standard EKC models, in that it focus on the problem of under-provision of a positive externality (ecosystem services) rather than the over-supply of a negative externality (pollution) [21]. Similarly, standard EKC models usually talk about an inverted U-shaped relationship between negative externality of environment and economic development, but a corresponding relationship between positive externality of environment and economic development should have varied along a U-shaped curve (Figure 1). In addition, most previous EKC research describes the changes of environmental status, without identifying the underlying factors responsible for the shape of the curve [24]. The status of agroecosystems delivering ES (one of environmental status) depends on many factors which include farmers' environmental awareness, farm size and local policies [25]. Furthermore, farmers' environmental awareness (attitudes) are strongly influenced by economic and demographic characteristics [26,27].Thus, the hypothesis of EKC is used as the theoretical core to identify trajectories of farmers' attitude changes toward the environment and explain how these changes are driven by socioeconomic and demographic characteristics [24,28]. In other words, the hypothesis of EKC provides an analytical framework that can be used to explore the dynamic interactions between concerns for ES and economic output of agriculture, which can provide useful information for the design of future agro-environmental policy. 


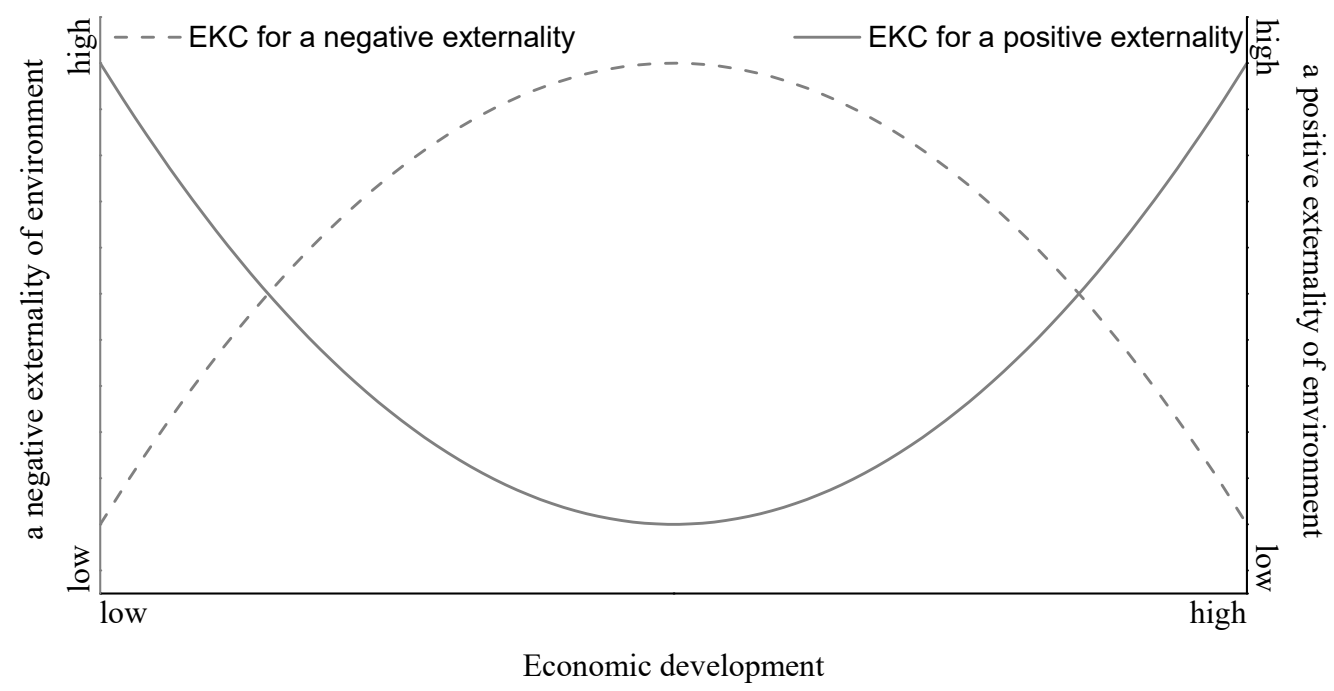

Figure 1. Schematic of inversed U-shaped environmental Kuznets curve (EKC) hypothesis for negative externality and U-shaped EKC hypothesis for positive externality (adapted from Wang et al., 2015 [29]).

In sum, greater understanding related to local farmers' strong perceptions about the ES is a prerequisite to improve both environmental effectiveness and economic efficiency in sustainable agroecosystems development. These perceptions convey both how to underpin the ES, which has received considerable attention, and how to use information to shape policies and incentives for better management of agroecosystems. Consequently, three objectives can be identified from this study: (1) Measure the farmers' attitudes toward ecosystem services by using their perceptions in Mengyin County, Shandong Province. (2) Focus on possibility that the relationships between annual household income and attitudes of farmers toward ES may be described as an upright U-shaped curve. If a statistically significant curve exists, where does its inflection point occur? (3) Whether and how social demographic characteristics affect the attitudes toward ES, and what are the underlying meanings?

\section{Methods}

\subsection{Study Area}

This study area is located in Mengyin County, in the hinterland of the Yimeng mountain area in south-central Shangdong province, China (Figure 2). Mengyin County covers $1602 \mathrm{~km}^{2}$ and has a warm temperate monsoon continental climate, with an average annual temperature of $12.8^{\circ} \mathrm{C}$ and an approximate annual rainfall of $800 \mathrm{~mm}$. Mengyin County is rich in forest resources, covering almost $15 \%$ of total area, known as a "natural oxygen bar", and is the national key soil erosion control county. Mengyin County has developed water system, covered about $5 \%$ of total area, and it incorporates the Dongwen, $\mathrm{Zi}$, and Meng Rivers. Yunmeng Reservoir (the regional center of the area) fed by the Dongwen and Zi Rivers has been designated as Linyi urban drinking water source since 1996 [10]. Agriculture is an important enterprise in Mengyin County occupying $93,680 \mathrm{hm}^{2}$, approximately $60 \%$ of the total area, and the large agricultural land includes $46 \%$ peach trees, $14 \%$ corn, $13 \%$ wheat, $12 \%$ peanut and $2 \%$ flue-cured tobacco [10]. Input intensive peach orchards have rapidly expanded, which is an important factor that causes non-point source pollution in Mengyin County. Therefore, the risk of soil pollution is getting bigger, which is highly related to ES resilience. In addition, this region has a number of resource assets such as national parks (e.g., Mengshan forest park) and culturally significant areas (e.g., the Memorial for the Battle in Menglianggu) that make it an interesting case for the study of farmers' attitudes in relation to ecosystem services [10]. 


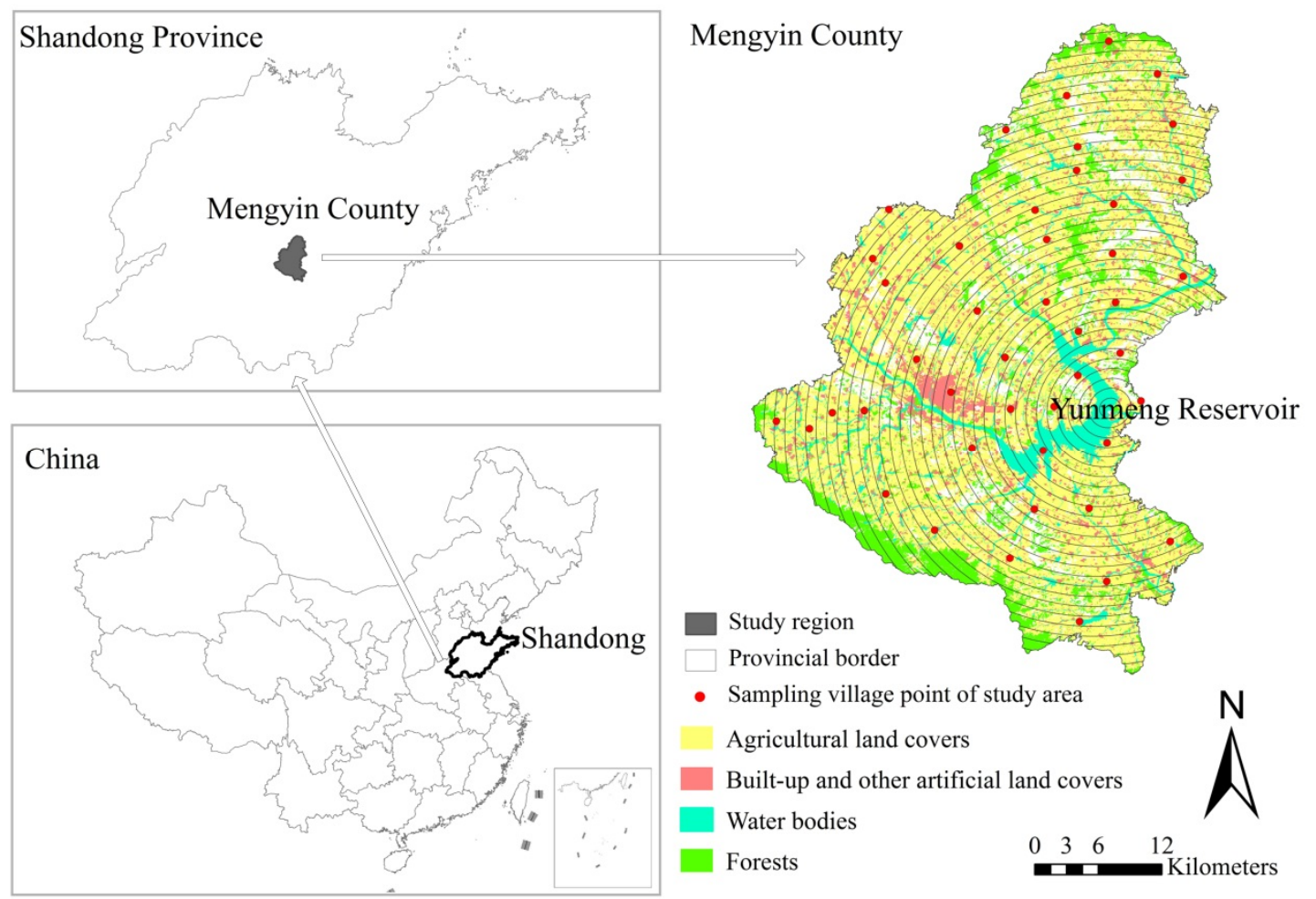

Figure 2. The location of the study regions (shaded dark) and sampling point of the study area (Chen et al., 2017 [10]).

\subsection{Data Collection}

A total of 216 farmers were selected through a hierarchical sampling method with the following three steps: (1) With Yunmeng reservoir as the center, a buffer zone was established at an interval of $1 \mathrm{~km}$ and there were 39 buffer zones. (2) Each buffer zone randomly selected one or two villages as sampling points and there were 44 sampling village. (3) From each sampling village, 4-6 farmers were selected randomly, and a total of216farmers were interviewed by face-to-face interviews (Figure 2) [10]. The face-to-face interviews contained two sections. In Section 1, the interview focused on the general characteristics of the farmers, including age, gender, education, household cultivated land area, annual household income, cropstrains and willingness to participate in payments for ecosystem services (PES) schemes. In Section 2, 10-point Likert scales were applied to measure relative importance of ES (waste assimilation, water regulation, pollination, biological pest control and maintenance of natural genetic diversity) for local farmers. The responses from the farmers on the relative importance of ES were ranked from 1 to 10 (low to high). A pre-survey was conducted in June 2015, and the final survey was conducted in August 2015 in Mengyin County.

\subsection{Data Analysis}

Although traditional environmental Kuznets curve researches focus on longitudinal or cross-regional studies based on time-series data, longitudinal data and cross-sectional data, this study used data in a novel way: the annual household income of different demographic groups were used as a proxy for changes in annual household income over a longer period or different region. This approach implicitly assumes that all demographic groups considered follow the same agricultural development path. The assumption that this approach is valid must be confirmed through future research, but it offers an interesting way to gain insights into the effects of attitudes on critical services without requiring many years of study. Additionally, data in the study area were collected using face-to-face interviews based on stratified random sampling surveys, thus providing a statistically robust dataset 
and high representativeness for the surveyed populations. As mentioned above, the range of values for the points in regression equations were defined to underst and differences in attitudes toward critical services at different income levels and as a function of education level, household cultivated land area and age (Table 1).

Table 1. Category and the range of values of the general characteristics for the farmers.

\begin{tabular}{|c|c|}
\hline Characteristics of the Farmers & Category and the Range of Values \\
\hline Annual household income (RMB) & $\begin{array}{c}\text { Quantity (Yuan) }<10,000,10,000-20,000,20,000-30,000, \\
30,000-40,000,40,000-50,000,50,000-60,000,60,000-70,000, \\
70,000-80,000,80,000-90,000,90,000-100,000,>100,000 \\
\text { Never attend school, Primary school (a total of } 6 \text { years), }\end{array}$ \\
\hline Educational level & $\begin{array}{c}\text { Middle school (9 years), High school (12 years), and } \\
\text { College (15 years) or university (16 years) }\end{array}$ \\
\hline Household cultivated land area $(\mathrm{mu})$ & Quantity $(\mathrm{mu})<3,3-7,8-12,13-17,>17$ \\
\hline Age & $\begin{array}{c}18-22,23-27,28-32,33-37,38-42,43-47 \\
48-52,53-57,58-62,63-67,>67\end{array}$ \\
\hline Gender & Male, Female \\
\hline $\begin{array}{l}\text { Willingness to participate in payments for } \\
\text { ecosystem services (PES) schemes }\end{array}$ & Willing, Unwilling \\
\hline Crop types & Grain crops, Fruit crops, Mixed crops \\
\hline
\end{tabular}

The survey data were analyzed by using the IBM ${ }^{\circledR}$ SPSS 20 software (IBM, Armonk, NY, USA) and R software (The University of Auckland, Auckland, New Zealand). The statistical methods were adopted to interpret the data, including the independent-samples t-test which compared the values for each pair of groups to determine whether any two groups differed significantly, and a one-way analysis of variance which compared the differences among more than two groups. When the result was significant $(p<0.05)$, independent-samples t-test and a one-way analysis of variance test identified group values that differed significantly. Because the data distribution showed a U-shaped curve for most datasets, $\mathrm{R}$ software performed nonlinear regression to describe these curves and quantitatively revealed the position of the inflection point. The coefficient of determination $\left(R^{2}\right)$ was used to judge the quality of the regression models. A regression model was accepted if the variance explained by the model was higher than $50 \%$ at a significance level of $p<0.05$.

\section{Results}

\subsection{The Attitudes toward Ecosystem Services}

The importance of ES for local farmers is presented in Table 2. The ecosystem services which were considered in this study were perceived by farmers as being lowly to highly important (median $=3-8$, mean $=4.29-7.20)$ with a relatively large variation $(S D=2.123-2.753)$, as shown in Table 2 . The results highlight that the relative importance of ES perceived by farmers are ranked as follows: water regulation ( median $=8$, mean $=7.20)$, pollination $($ median $=6$, mean $=5.70)$, biological pest control $($ median $=5$, mean $=4.88)$, maintenance of natural genetic diversity (median $=5$, mean $=4.70)$ and waste assimilation (median $=3$, mean $=4.29$ ). Simultaneously, differences in perceptions of relative importance of ES exist among different farmer groups (Tables 3 and 4). The results stress that gender has a significant role in determining farmers perceptions about the importance of ES. Women had lower perception of important value than men; particularly, the values of male perceptions about the importance of biological pest control and maintenance of natural genetic diversity were significantly higher than female perceptions ( $p=0.015, p=0.016$, Table 3). Additionally, the results indicate that the values of the importance of ES perceived by farmers who were willing to participate in PES schemes tended to be higher than the farmers who were unwilling to participate in PES schemes, and the values perceived by the willing farmers about the importance of biological pest control and maintenance of natural genetic diversity were significantly higher than the unwilling farmers $(p=0.012, p=0.007$, Table 3$)$. Among the 
farmers who plant different crop types, the perceptions of relative importance of ES were different, whereas the differences were not statistically significant except for waste assimilation. The value of the importance of waste assimilation perceived by farmers who plant fruit crops tended to be significantly higher than the farmers who plant grain crops, and the value perceived by farmers who plant mixed crops was not significantly different between others $(p=0.037$, Table 4$)$.

Table 2. Summary statistics of local farmers' attitudes toward ecosystem services (the importance of ecosystem services for local farmers).

\begin{tabular}{|c|c|c|}
\hline Ecosystem Services & Measure & Value \\
\hline \multirow{5}{*}{ Waste assimilation } & Mean & 4.29 \\
\hline & Median & 3 \\
\hline & Standard deviation & 2.663 \\
\hline & Minimum & 1 \\
\hline & Maximum & 10 \\
\hline \multirow{5}{*}{ Water regulation } & Mean & 7.20 \\
\hline & Median & 8 \\
\hline & Standard deviation & 2.123 \\
\hline & Minimum & 1 \\
\hline & Maximum & 10 \\
\hline \multirow{5}{*}{ Pollination } & Mean & 5.70 \\
\hline & Median & 6 \\
\hline & Standard deviation & 2.743 \\
\hline & Minimum & 1 \\
\hline & Maximum & 10 \\
\hline \multirow{5}{*}{ Biological pest control } & Mean & 4.88 \\
\hline & Median & 5 \\
\hline & Standard deviation & 2.753 \\
\hline & Minimum & 1 \\
\hline & Maximum & 10 \\
\hline \multirow{5}{*}{ Maintenance of natural genetic diversity } & Mean & 4.70 \\
\hline & Median & 5 \\
\hline & Standard deviation & 2.747 \\
\hline & Minimum & 1 \\
\hline & Maximum & 10 \\
\hline
\end{tabular}

Table 3. The importance of ecosystem services perceived by respondents relative to gender and interest in participation in PES schemes.

\begin{tabular}{|c|c|c|c|c|c|c|}
\hline \multirow{2}{*}{$\begin{array}{l}\text { Relative Importance of } \\
\text { Ecosystem Services }\end{array}$} & \multicolumn{2}{|c|}{ Gender } & \multirow[t]{2}{*}{$p$-Value } & \multicolumn{2}{|c|}{$\begin{array}{l}\text { Willingness to Participate } \\
\text { in PES Schemes }\end{array}$} & \multirow[t]{2}{*}{$p$-Value } \\
\hline & Male & Female & & Willing & Unwilling & \\
\hline Waste assimilation & $4.41 \pm 2.610$ & $4.00 \pm 2.780$ & 0.300 & $4.37 \pm 2.683$ & $3.95 \pm 2.578$ & 0.371 \\
\hline Water regulation & $7.38 \pm 2.035$ & $6.78 \pm 2.278$ & 0.061 & $7.25 \pm 2.080$ & $6.98 \pm 2.315$ & 0.464 \\
\hline Pollination & $5.79 \pm 2.820$ & $5.52 \pm 2.579$ & 0.505 & $5.87 \pm 2.729$ & $4.95 \pm 2.745$ & 0.055 \\
\hline Biological pest control & $5.17 \pm 2.797$ & $4.18 \pm 2.537$ & $0.015^{*}$ & $5.10 \pm 2.757$ & $3.90 \pm 2.548$ & $0.012 *$ \\
\hline $\begin{array}{l}\text { Maintenance of natural } \\
\text { genetic diversity }\end{array}$ & $4.98 \pm 2.851$ & $4.06 \pm 2.398$ & $0.016^{*}$ & $4.93 \pm 2.769$ & $3.70 \pm 2.441$ & $0.007^{* *}$ \\
\hline
\end{tabular}


Table 4. The importance of ecosystem services perceived by respondents who plant different crop types.

\begin{tabular}{ccccc}
\hline \multirow{2}{*}{$\begin{array}{c}\text { Relative Importance of } \\
\text { Ecosystem Services }\end{array}$} & Grain Crops & Fruit Crops & Mixed Crops & \multirow{2}{*}{$p$-Value } \\
\cline { 2 - 4 } & $3.59 \pm 2.245^{\mathrm{a}}$ & $4.60 \pm 2.842^{\mathrm{b}}$ & $4.47 \pm 2.658^{\mathrm{ab}}$ & $0.037^{*}$ \\
Waste assimilation & $7.26 \pm 2.151$ & $7.48 \pm 2.000$ & $6.68 \pm 2.228$ & 0.071 \\
Water regulation & $5.08 \pm 2.661$ & $5.92 \pm 2.849$ & $5.967 \pm 2.617$ & 0.127 \\
$\quad \begin{array}{c}\text { Pollination } \\
\text { Biological pest control }\end{array}$ & $5.02 \pm 2.668$ & $4.78 \pm 2.845$ & $4.90 \pm 2.723$ & 0.866 \\
Maintenance of natural & $4.32 \pm 2.467$ & $4.73 \pm 2.956$ & $4.02 \pm 2.655$ & 0.386 \\
genetic diversity & & & &
\end{tabular}

\subsection{The Relationships between Annual Household Income, Demographic Characteristics and Attitudes toward Ecosystem Services}

The results suggest that the relationships between annual household income and attitudes toward ES are non-linear and the regression models under all critical services are accepted (Figure 3A1-E1). This indicates that relationships between attitude toward waste assimilation, biological pest control and annual household income imply the possible existence of a U-shaped curve (Figure 3A1,D1), and the first derivative of the second order polynomial regression curves for waste assimilation and biological pest control suggest the inflection points for attitudes are at annual household incomes of 17,091 and 25,071 RMB (US\$2747 and US $\$ 4030$ at an exchange rate of approximately $6.22 \mathrm{RMB} / \mathrm{US} \$$ in 2015). That is, if the annual household income is less than 17,091 and 25,071 RMB, then farmers will prefer to increase their income rather than to focus on waste assimilation and biological pest control, and the desire to pay more attention to waste assimilation and biological pest control will not exceed the desire for economic growth until the annual household income is more than 17,091 and 25,071 RMB. However, the shape of the curves for water regulation, pollination and maintenance of natural genetic diversity show that as annual household income increases, the values of the importance of water regulation, pollination and maintenance of natural genetic diversity continue to increase (Figure 3B1,C1,E1). This would imply that as annual household income increase, farmers increasingly pay more attention to water regulation, pollination and maintenance of natural genetic diversity.

In general, the second order polynomial regression curves for all critical services suggest that as the education level of the farmers increase, their attention toward ES increases gradually (Figure 3A2-E2). However, with the exception of waste assimilation, these association relationships are not significant $(p>0.05)$. Simultaneously, the results show that the values of the importance of waste assimilation, pollination, biological pest control and maintenance of natural genetic diversity are initially expected to rise with an increase in household cultivated land area and then fall after household cultivated land area passes beyond a certain critical threshold (cultivation area "turning points" are 12.65, 12.66, 15.17 and $12.40 \mathrm{mu}$, respectively) (Figure 3A3,C3-E3). However, these association relationships are not significant $(p>0.05)$. In addition, the regression models of relationships between attitudes toward water regulation, maintenance of natural genetic diversity and age are accepted, and the values of the importance decline with the increasing of age (Figure 3B4,E4).

\subsection{The Contributions of This Research}

The contributions of this research show in the following aspects. (1) This study introduces the farmers' perception of the importance of ecosystem services into the process of ES evaluation and application of agroecosystems, and contributes to agricultural environment protection research. (2) This research detects the impact of farmers' general characteristics on their ES perception and extends the research on the factors affecting farmers' ES perception. (3) Based on the environmental Kuznets curve (EKC) theory, this study examines the relationship between household income level and farmers' ES perception, revealing the important role of economic drivers at the micro level. 

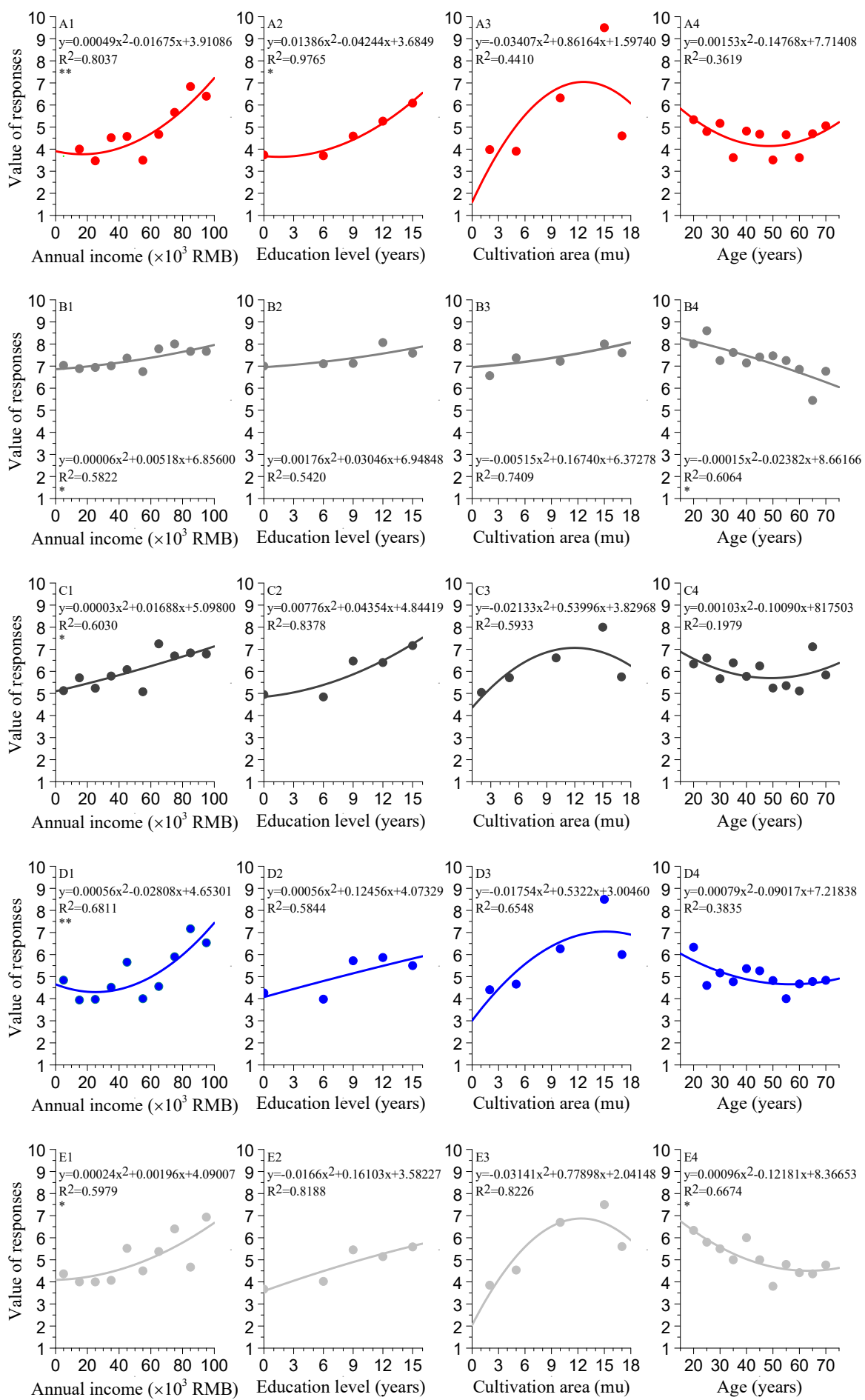

10
10

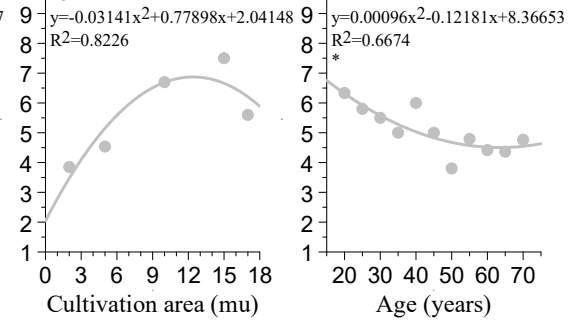

- Waste assimilation

- Biological pest control

- Water regulation

- Pollination

Figure 3. Attitudes of farmers toward ecosystem services as a function of annual household income, education level, household cultivated land area and age. For annual household income, household cultivated land area and age, values are plotted at the midpoint of the categories defined in Table 1. Response values for the attitudes toward ES (the relative importance of ES) are ranked from 1 to 10 (low to high), and higher values represent more concerns about the ES.* $p<0.05,{ }^{* *} p<0.01$. 


\section{Discussion}

\subsection{Farmers'Attitudinal Responses on Ecosystem Services}

Since farmers are directly responsible for taking decisions and managing agroecosystems, strategies for improving environmental sustainability of ecosystem functioning should consider their attitudinal responses on ecosystem services [30,31]. Nevertheless, perceptions of ecosystem services are multifactorial constructs that can also be influenced by individual characteristics and local PES [10,32-34]. The results stress that gender influences farmers' perceptions of relative importance of ES: male farmers are more cognizant of the importance of ES, notably for biological pest control and maintenance of natural genetic diversity. This is similar to the findings of other studies which demonstrate male farmers are more aware of ES and more likely to perceive the less obvious ES [35-37], probably because the less obvious ES (e.g., maintenance of natural genetic diversity) indirectly impacts farmers and requires some degree of ecological knowledge to be understood. On one hand, direct work on farmland promotes better opportunities for male famers to gain more experience with ecological processes [34]. On the other hand, older male farmers with more years of formal education may be capable of increasing cognitive abilities and improving their perception of surroundings (in this study, the years male farmers received formal education is significantly higher than the years female farmers received the same; the average years of formal education are 8.10 and 6.53, respectively. The male farmers are also significantly older than the female farmers; the average ages are 51 and 47, respectively). Considering the different situations of the farmers' crop type, the main differences in perceptions about relative importance of ES among grain crops farmers, fruit crop farmers and mixed crop farmers are pollination and waste assimilation. Indeed, both fruit crop farmers and mixed crop farmers recognized more importance of pollination, since many fruit varieties are not self-pollinating and pollination is an essential driving force of crop production [38-40]. Additionally, some farmers said pesticides they used may impair bee colonies. The need to reduce pollinator exposure to harmful pesticides has led them to appeal to expedite the adoption of integrated pest and pollinator management [41]. Fruit crop farmers also recognized a significantly higher value of the importance of waste assimilation than grain crop farmers, since they apply more organic fertilizers through waste assimilation with the aim of sustaining or improving soil fertility and fruit quality. In fact, there is some evidence that this is the case $[42,43]$.

This study also shows that the perception of farmers on relative importance of ES is interconnected with farmers' willingness to participate in PES schemes. Farmers who are willing to participate in PES schemes are more aware of the importance of ES. On one hand, acceptance of PES schemes which offer financial compensation for the costs of certain management actions is likely to strengthen perceptions that ecosystem services are valuable [44-46]. On the other hand, the farmers who endorse ES values are likely to accept PES schemes as an effective way to manage farmland $[36,47,48]$. Payments for ecosystem services have attracted increasing interest as a mechanism to encourage an effective combination of environmental protection with agricultural production (e.g., the US Conservation Security Program (CSP) and the European agri-environment schemes (AES)) $[1,49,50]$. At present, China's agricultural PES programs are still in the initial stages and land consolidation in China always focuses on the two core objectives of replenishing arable land and improving agricultural infrastructure [10,51]. Land consolidation in China is experiencing a transformation toward sustainability, which may improve the link between payments and the provision of ecosystem services in agricultural PES programs. Thus, before a series of environmental conservation measures based on economic instruments would be widely adopted to improve the status quo of agricultural ES, it is crucial to assess farmers' existing intrinsic motivations [52]. For instance, this study shows that for the farmers interviewed, water regulation was the most important ES, probably because climatic factors have stronger economic impacts to producers and that is especially true for food producers, who rely upon proper water management to sustain food production. This highlights the need for agricultural PES programs aiming at water-conservation function through practices already familiar to farmers, 
such as small scale reservoir irrigation systems, riparian strips vegetation management and improving soil quality. Furthermore, the variation in the farmers' perceptions on ES found in this study triggers the question to whether a relative widespread adoption of future environmental conservation measures should match with the way how farmers understand their own agroecosystem. Firstly, initiatives that aim to strengthen agricultural ES provision should be sensitive to farmer's perceptions and may need to consider using specific strategies for different farmer types [31]. For example, fruit crop farmers could be encouraged to implement measures synergetic benefits from pollination and biological pest control services. Secondly, environmental conservation measures should prioritize informal environment education to promote scientific knowledge of ES [30,34]. In summary, what is needed are flexible, intelligent agricultural PES programs more suited to local requirements.

\subsection{Unravelling Attitudinal Change of Farmers toward Ecosystem Services through the EKC Theory}

Environmental Kuznets curves are not just used to analyze the relationship between economic development and positive externality of environment $[29,53,54]$, but also to explain the strong environmental concerns of people by individual or micro level incomes $[55,56]$. Therefore, this study introduces annual household income of farmers as a moderating variable at the micro level to understand how the attitudes toward ES changed with annual household income level. The results show two scenarios: steady growth curves for water regulation, pollination and maintenance of natural genetic diversity or U-shaped curves for waste assimilation and biological pest control (Figure 3A1-E1). This suggests that more positive attitudes toward ES are held by farmers with higher income, showing that financial means are key determinants of farmers' environmental attitudes. The moderating effect of farmers' income level on attitudes toward ES can be understood as two aspects. On one hand, rising household income of farmers will not in itself ensure improvements in agricultural environment performance [56,57]. Considering the specific Chinese setting, compared with farmers in developed countries, Chinese farmers are excessively financially dependent on farmland [56]. For example, in the EU member states, AES has been implemented through contracts between public institutions and farmers, and requires farmers to change their farming practices in order to improve ecosystem services and in return for compensation per hectare of land $[48,56,58,59]$. AES offer financial compensation which help to reduce farmers' dependence on farming income, thereby reducing the risk of ecosystem services loss [56,60,61]. However, in China, the economic and policy environment is very different. For example, the Grain to Green Program (GTGP) converts cropland on steep slopes to forest and grassland, and mainly relates to structural changes in forestry and agriculture [10,62]. Additionally, the income of Chinese farmers has improved since the reform of the "household contract responsibility system", but farmers' dependence on farming income driven by intensively farmed land is still very high, which reduces and threatens the ecological and financial contribution of some ES [56,63,64]. On the other hand, the underlying implication of ES attention is farmers' insight that conventional agriculture practice endanger ES, combined with the willingness to protect and restore ES [1,65-68]. The underlying implication consists of two components, the cognitive component of having the rational insight (when ES perceived by farmers are fragile which limits support for yields, it leads to call for ES attention) and the conative component of being willing to do something about it (a robust growth in ES attention would result in actual benefits for the agricultural environment). Actually, the insight may reflect two explanations that an increase in annual household income leads to higher agricultural environment pressure per unit of income and income growth is supposed to cause changes in farmers' values, consciousness and preferences, producing increasing attention for agricultural environment quality [56,69-72]. For the conative component, farmers' attitude could positively affect their behavior, however gaps exist between the expression of attitudes toward ES and the actual behavior performed by the majority of individuals in everyday choices [73,74]. The improvement of ES often strongly depends on collective behaviors with limited possibilities for the single individual to make any difference by changing his or her course of action [10,75]. Thus, farmers' attitudes can affect agricultural environment quality by influencing individual behavior, but their actual effect also depends on the broader system 
of incentives produced by social, economic and institutional environments [69]. As mentioned above, even if the awareness of importance for ES somewhat increases in high-income farmers, it is unlikely that based on farmers' household income forces could lead by themselves to an improvement of agricultural ES. It is quite necessary to create the right incentives to advocate for environmentally friendly farming practices to tackle the preservation and restoration of ES and increase farmers' income together, and incentives then can enhance the positive outcomes from income growth.

To create reasonable incentives (e.g., agricultural PES programs) for the farmers based on the EKC, the point where farmers decide to exchange more attention on farmland income for more attention on ES (the income at which priorities change from income to ES attention) could provide an important reference. The results indicate that turning points for waste assimilation at 17,091 RMB in annual household income and at 25,071 RMB for biological pest control are identified, after which further household income growth tends to pay more attention to waste assimilation and biological pest control (Figure 3A1,D1). In the other words, after the 17,091 RMB or 25,071 RMB monetary foundations, farmers can start adding emphasis to waste assimilation or biological pest control rather than first and foremost caring about their monetary returns. According to results, the values of the importance of water regulation, pollination and maintenance of natural genetic diversity tend to increase with annual household income growth (Figure 3B1,C1,E1). This may reflect rising tensions on water regulation, pollination and maintenance of natural genetic diversity in the opinions of farmers rather than first and foremost caring about their monetary returns. In these situations, non-monetary incentives (e.g., agricultural infrastructure development, information sharing and technical support) may work better as a reasonable mechanism for improving maintenance of these ES [69,76,77]. Apart from monetary and non-monetary incentives linked to environmentally beneficial attitudes and behavior, farmers' attitudes toward ES also depend on individuals' socio-demographic characteristics (such as age, education and farmland scale of household). Specifically, as the education level of the farmers increases, their perceptions of the importance of ES gradually increase (Figure 3A2-E2). Education enables farmers to consider the marginal cost and benefit of ES and recognize the direct impact of ES on their agricultural production, thus educational attainment has a strong effect on ES concerns [10,34,78]. It can be obtained from Figure 3A3,C3-E3, as household cultivated land area grow, that the values of the importance of waste assimilation, pollination, biological pest control and maintenance of natural genetic diversity initially rise and then decrease; meanwhile, cultivation area "turning points" are $12.65,12.66,15.17$ and $12.40 \mathrm{mu}(0.84,0.84,1.01$ and $0.83 \mathrm{ha})$, respectively. According to survey, the average household cultivated land area is $5.25 \mathrm{mu}(0.35 \mathrm{ha})$ and is smaller than every critical threshold. In this case, based on published literatures relating the impact of cultivated land size on agricultural sustainability, that increase in cultivated land size is associated with the improvement of environmental performances $[68,79]$. Farmers who are younger in age are inclined to contribute attention on ES (Figure 3B4,E4). There is evidence that the educational level of younger farmers is significantly higher than that of older farmers, and young farmers are more aware of ES [36,56]. In sum, education, age and cultivation area do affect the farmers' perceptions of ES. Additionally, an increase in years of formal education and farming area would be pathways for the improvement of agricultural ES.

\subsection{Implications, Limitations and Perspective}

Based on environmental Kuznets curve theory, this study seeks to understand the interconnections between farmers' attitudes toward ecosystem services and their annual household income for supporting sustainable development of agriculture. This research conclude that as PES programs for environment conservation have been most focused worldwide, it is crucial to create not only reasonable monetary incentives but also reasonable non-monetary incentives for improving farmers' attitudes toward ES to restore agricultural environment and help increase household income. For example, subsidies should be used to promote farmers caring about ES and take measures to protect and restore ES. The results heighten the importance to enhance farmers' attitudes toward ES and clarify the factors affecting farmers' ES perception. However, due to various restrictions, there are 
some limitations in this research reflecting in the following two aspects. On the one hand, survey data cannot reveal the time effect on farmers' perception of ES importance. Therefore, future research should collect survey data across a time period for enhancing the robustness of the results. On the other hand, this research has not addressed the implications of spatial spillover effects in explaining farmers' perception of ES. Therefore, future research should explore spatial dependence about farmers' attitudes toward ES to make effective local policies.

\section{Conclusions}

This study highlights the farmer's attitudes on ES and the trajectories of farmers' attitude toward ES change caused by annual household income and social demographic characteristics which are helpful in providing references for agricultural environment management. The results reveal that, in general, the perceptions of farmers' attitudes on ES are highly complex and attributed to characteristics of the farmers. The trajectory of farmers' attitude change caused by annual household income follows steady growth curves for water regulation, pollination and maintenance of natural genetic diversity, and U-shaped curves for waste assimilation and biological pest control. The inflection points of the U-shaped curves, where priorities change from increasing income to paying more attention to waste assimilation and biological pest control, are identified at 17,091 and 25,071 RMB, respectively and could provide important references for reasonable incentives (e.g., agricultural PES programs). Furthermore, farmers' attitudes of ES can affect agricultural environment quality, but their actual effect also depends on the broader system of education, land management and incentives produced by social, economic and institutional environments. Therefore, it is necessary to strengthen the farmers educational attainment, concentrate fragmented cultivation area and create reasonable incentives (including monetary and non-monetary incentives) for improving farmers' attitudes toward ES to support sustainable development of agriculture.

Author Contributions: Conceptualization, methodology, software and formal analysis, Y.Y. and Y.C.; investigation and data curation, Y.C., P.L. and X.L.; writing—original draft preparation, Y.Y.; writing — review and editing, Y.Y. and Y.C.; project administration, Z.Y. and Y.C. All authors have read and agreed to the published version of the manuscript.

Funding: This research was funded by National Natural Science Foundation of China (No. 41671181), Ecological Environment Project of Ministry of Agriculture and The Initial Foundation of Scientific Research for the introduction of talents of Inner Mongolia Normal University (2018YJRC035).

Acknowledgments: We would like to thank the colleagues from China Agricultural University, Inner Mongolia Normal University and Mengyin County Government for their help in the survey of farmers. We thank the farmers for their cooperation and patience in the interview. We also thank the anonymous reviewers for their help in improving this paper.

Conflicts of Interest: The authors declare no conflict of interest.

\section{References}

1. Power, A.G. Ecosystem services and agriculture: Tradeoffs and synergies. Philos. Trans. R. Soc. B Biol. Sci. 2010, 365, 2959-2971. [CrossRef] [PubMed]

2. Joshua, J. The environmental effects of overconsumption. In The Economics of Addictive Behaviours Volume IV: The Private and Social Costs of Overeating and Their Remedies; Springer International Publishing: Cham, Switzerland, 2017; pp. 67-73.

3. Mendenhall, C.D.; Karp, D.S.; Meyer, C.F.J.; Hadly, E.A.; Daily, G.C. Predicting biodiversity change and averting collapse in agricultural landscapes. Nature 2014, 509, 213-217. [CrossRef] [PubMed]

4. Liu, L.; Di, B.; Zhang, M. The tradeoff between ecological protection and economic growth in China's county development: Evidence from the soil and water conservation projects during 2011-2015. Resour. Conserv. Recycl. 2020, 156, 104745. [CrossRef]

5. Cumming, G.S.; Buerkert, A.; Hoffmann, E.M.; Schlecht, E.; von Cramon-Taubadel, S.; Tscharntke, T. Implications of agricultural transitions and urbanization for ecosystem services. Nature 2014, 515, 50-57. [CrossRef] [PubMed] 
6. Chen, X.; Shuai, C.; Zhang, Y.; Wu, Y. Decomposition of energy consumption and its decoupling with economic growth in the global agricultural industry. Environ. Impact Assess. Rev. 2020, 81, 106364. [CrossRef]

7. Assessment, M.E. Ecosystems and Human Well-Being, 5th ed.; Island Press: Washington, DC, USA, 2005.

8. Godfray, H.C.J.; Beddington, J.R.; Crute, I.R.; Haddad, L.; Lawrence, D.; Muir, J.F.; Pretty, J.; Robinson, S.; Thomas, S.M.; Toulmin, C. Food security: The challenge of feeding 9 billion people. Science 2010, 327, 812-818. [CrossRef]

9. Grossman, J.J. Ecosystem service trade-offs and land use among smallholder farmers in eastern Paraguay. Ecol. Soc. 2015, 20, 15. [CrossRef]

10. Chen, Y.; Zhang, Q.; Liu, W.; Yu, Z. Analyzing farmers' perceptions of ecosystem services and PES schemes within agricultural landscapes in Mengyin county, China: Transforming trade-offs into synergies. Sustainability 2017, 9, 1459. [CrossRef]

11. Bommarco, R.; Vico, G.; Hallin, S. Exploiting ecosystem services in agriculture for increased food security. Glob. Food Secur. 2018, 17, 57-63. [CrossRef]

12. Tamburini, G.; de Simone, S.; Sigura, M.; Boscutti, F.; Marini, L. Soil management shapes ecosystem service provision and trade-offs in agricultural landscapes. Proc. R. Soc. B Biol. Sci. 2016, 283, 20161369. [CrossRef]

13. Tamburini, G.; Bommarco, R.; Kleijn, D.; van der Putten, W.H.; Marini, L. Pollination contribution to crop yield is often context-dependent: A review of experimental evidence. Agric. Ecosyst. Environ. 2019, 280, 16-23. [CrossRef]

14. Westerman, P.; Bicudo, J. Management considerations for organic waste use in agriculture. Bioresour. Technol. 2005, 96, 215-221. [CrossRef] [PubMed]

15. Jia, W.; Qin, W.; Zhang, Q.; Wang, X.; Ma, Y.; Chen, Q. Evaluation of crop residues and manure production and their geographical distribution in China. J. Clean. Prod. 2018, 188, 954-965. [CrossRef]

16. Tooker, J.F.; O'Neal, M.E.; Rodriguez-Saona, C. Balancing disturbance and conservation in agroecosystems to improve biological control. Annu. Rev. Entomol. 2020, 65, 81-100. [CrossRef]

17. Gordon, L.J.; Finlayson, C.M.; Falkenmark, M. Managing water in agriculture for food production and other ecosystem services. Agric. Water Manag. 2010, 97, 512-519. [CrossRef]

18. Hajjar, R.; Jarvis, D.I.; Gemmill-Herren, B. The utility of crop genetic diversity in maintaining ecosystem services. Agric. Ecosyst. Environ. 2008, 123, 261-270. [CrossRef]

19. Kuznets, S. Economic growth and income inequality. Am. Econ. Rev. 1955, 45, 1-28.

20. Panayotou, T. Empirical Tests and Policy Analysis of Environmental Degradation at Different Stages of Economic Development; International Labour Organization: Geneva, Switzerland, 1993.

21. Omer, A.; Pascual, U.; Russell, N. Agricultural Intensification and Biodiversity Loss: Is There an Agri-EKC; University of Manchester, School of Economic Studies: Manchester, UK, 2003.

22. Sarkodie, S.A.; Strezov, V. Empirical study of the environmental Kuznets curve and environmental sustainability curve hypothesis for Australia, China, Ghana and USA. J. Clean. Prod. 2018, 201, 98-110. [CrossRef]

23. Sarkodie, S.A.; Strezov, V. A review on environmental Kuznets curve hypothesis using bibliometric and meta-analysis. Sci. Total Environ. 2019, 649, 128-145. [CrossRef] [PubMed]

24. Zhang, J.; Luo, M.; Cao, S. How deep is China's environmental Kuznets curve? An analysis based on ecological restoration under the Grain for Green program. Land Use Policy 2018, 70, 647-653. [CrossRef]

25. Lan, K.; Yao, Y. Integrating Life cycle assessment and agent-based modeling: A dynamic modeling framework for sustainable agricultural systems. J. Clean. Prod. 2019, 238, 117853. [CrossRef]

26. Zeweld, W.; van Huylenbroeck, G.; Tesfay, G.; Speelman, S. Smallholder farmers' behavioural intentions towards sustainable agricultural practices. J. Environ. Manag. 2017, 187, 71-81. [CrossRef]

27. Dang, X.; Gao, S.; Tao, R.; Liu, G.; Xia, Z.; Fan, L.; Bi, W. Do environmental conservation programs contribute to sustainable livelihoods? Evidence from China's grain-for-green program in northern Shaanxi province. Sci. Total Environ. 2020, 719, 137436. [CrossRef]

28. Liu, X.; Mu, R. Public environmental concern in China: Determinants and variations. Glob. Environ. Change 2016, 37, 116-127. [CrossRef]

29. Wang, L.; Zhou, D.; Wang, Y.; Zha, D. An empirical study of the environmental Kuznets curve for environmental quality in Gansu province. Ecol. Indic. 2015, 56, 96-105. [CrossRef]

30. Chen, Y.; Yu, Z.; Li, X.; Li, P. How agricultural multiple ecosystem services respond to socioeconomic factors in Mengyin County, China. Sci. Total Environ. 2018, 630, 1003-1015. [CrossRef] [PubMed] 
31. Teixeira, H.M.; Vermue, A.J.; Cardoso, I.M.; Claros, M.P.; Bianchi, F.J. Farmers show complex and contrasting perceptions on ecosystem services and their management. Ecosyst. Serv. 2018, 33, 44-58. [CrossRef]

32. Orenstein, D.E.; Groner, E. In the eye of the stakeholder: Changes in perceptions of ecosystem services across an international border. Ecosyst. Serv. 2014, 8, 185-196. [CrossRef]

33. Cebrián-Piqueras, M.; Karrasch, L.; Kleyer, M. Coupling stakeholder assessments of ecosystem services with biophysical ecosystem properties reveals importance of social contexts. Ecosyst. Serv. 2017, 23, 108-115. [CrossRef]

34. Lima, F.P.; Bastos, R.P. Perceiving the invisible: Formal education affects the perception of ecosystem services provided by native areas. Ecosyst. Serv. 2019, 40, 101029. [CrossRef]

35. Sanogo, K.; Binam, J.; Bayala, J.; Villamor, G.B.; Kalinganire, A.; Dodiomon, S. Farmers' perceptions of climate change impacts on ecosystem services delivery of parklands in southern Mali. Agrofor. Syst. 2017, 91, 345-361. [CrossRef]

36. Xun, F.; Hu, Y.; Lv, L.; Tong, J. Farmers' awareness of ecosystem services and the associated policy implications. Sustainability 2017, 9, 1612. [CrossRef]

37. Andeltová, L.; Catacutan, D.C.; Wünscher, T.; Holm-Müller, K. Gender aspects in action-and outcome-based payments for ecosystem services-A tree planting field trial in Kenya. Ecosyst. Serv. 2019, 35, 13-22. [CrossRef]

38. Potts, S.G.; Biesmeijer, J.C.; Kremen, C.; Neumann, P.; Schweiger, O.; Kunin, W.E. Global pollinator declines: Trends, impacts and drivers. Trends Ecol. Evol. 2010, 25, 345-353. [CrossRef]

39. Demestihas, C.; Plénet, D.; Génard, M.; Raynal, C.; Lescourret, F. Ecosystem services in orchards. A review. Agron. Sustain. Dev. 2017, 37, 12. [CrossRef]

40. Samnegård, U.; Hambäck, P.A.; Smith, H.G. Pollination treatment affects fruit set and modifies marketable and storable fruit quality of commercial apples. R. Soc. Open Sci. 2019, 6, 190326. [CrossRef] [PubMed]

41. Egan, P.A.; Dicks, L.V.; Hokkanen, H.M.; Stenberg, J.A. Delivering integrated pest and pollinator management (IPPM). Trends Plant Sci. 2020, 25, 577-589. [CrossRef]

42. Roussos, P.A.; Gasparatos, D.; Kechrologou, K.; Katsenos, P.; Bouchagier, P. Impact of organic fertilization on soil properties, plant physiology and yield in two newly planted olive (Olea europaea L.) cultivars under Mediterranean conditions. Sci. Hortic. 2017, 220, 11-19. [CrossRef]

43. Milošević, T.; Milošević, N. Soil fertility: Plant nutrition vis-à-vis fruit yield and quality of stone fruits. In Fruit Crops; Elsevier: Amsterdam, The Netherlands, 2020; pp. 583-606.

44. Vanslembrouck, I.; van Huylenbroeck, G.; Verbeke, W. Determinants of the willingness of Belgian farmers to participate in agri-environmental measures. J. Agric. Econ. 2002, 53, 489-511. [CrossRef]

45. Smith, H.F.; Sullivan, C.A. Ecosystem services within agricultural landscapes-Farmers' perceptions. Ecol. Econ. 2014, 98, 72-80. [CrossRef]

46. Da Motta, R.S.; Ortiz, R.A. Costs and perceptions conditioning willingness to accept payments for ecosystem services in a Brazilian case. Ecol. Econ. 2018, 147, 333-342. [CrossRef]

47. Ryan, R.M.; Deci, E.L. Intrinsic and extrinsic motivations: Classic definitions and new directions. Contemp. Educ. Psychol. 2000, 25, 54-67. [CrossRef] [PubMed]

48. Tienhaara, A.; Haltia, E.; Pouta, E.; Arovuori, K.; Grammatikopoulou, I.; Miettinen, A.; Koikkalainen, K.; Ahtiainen, H.; Artell, J. Demand and supply of agricultural ES: Towards benefit-based policy. Eur. Rev. Agric. Econ. 2020, 47, 1223-1249. [CrossRef]

49. Ekroos, J.; Olsson, O.; Rundlöf, M.; Wätzold, F.; Smith, H.G. Optimizing agri-environment schemes for biodiversity, ecosystem services or both? Biol. Conserv. 2014, 172, 65-71. [CrossRef]

50. Vainio, A.; Tienhaara, A.; Haltia, E.; Hyvönen, T.; Pyysiäinen, J.; Pouta, E. The legitimacy of result-oriented and action-oriented agri-environmental schemes: A comparison of farmers' and citizens' perceptions. Land Use Policy 2019, 104358. [CrossRef]

51. Li, P.; Chen, Y.; Hu, W.; Li, X.; Yu, Z.; Liu, Y. Possibilities and requirements for introducing agri-environment measures in land consolidation projects in China, evidence from ecosystem services and farmers' attitudes. Sci. Total Environ. 2019, 650, 3145-3155. [CrossRef] [PubMed]

52. Rode, J.; Gómez-Baggethun, E.; Krause, T. Motivation crowding by economic incentives in conservation policy: A review of the empirical evidence. Ecol. Econ. 2015, 117, 270-282. [CrossRef]

53. Fan, C.; Zheng, X. An empirical study of the environmental Kuznets curve in Sichuan Province, China. Environ. Pollut. 2013, 2, 107. [CrossRef]

54. Benedek, Z.; Fertő, I. Does economic growth influence forestry trends? An environmental Kuznets curve approach based on a composite Forest Recovery Index. Ecol. Indic. 2020, 112, 106067. [CrossRef] 
55. Ficko, A.; Bončina, A. Public attitudes toward environmental protection in the most developed countries: The Environmental Concern Kuznets Curve theory. J. Environ. Manag. 2019, 231, 968-981. [CrossRef]

56. Zhou, Z.; Liu, J.; Zeng, H.; Zhang, T.; Chen, X. How does soil pollution risk perception affect farmers' pro-environmental behavior? The role of income level. J. Environ. Manag. 2020, 270, 110806. [CrossRef] [PubMed]

57. Rudi, L.-M.; Azadi, H.; Witlox, F. Reconcilability of socio-economic development and environmental conservation in Sub-Saharan Africa. Glob. Planet. Change 2012, 86, 1-10. [CrossRef]

58. Reed, M.S.; Moxey, A.; Prager, K.; Hanley, N.; Skates, J.; Bonn, A.; Evans, C.D.; Glenk, K.; Thomson, K. Improving the link between payments and the provision of ecosystem services in agri-environment schemes. Ecosyst. Serv. 2014, 9, 44-53. [CrossRef]

59. Morren, M.; Grinstein, A. Explaining environmental behavior across borders: A meta-analysis. J. Environ. Psychol. 2016, 47, 91-106. [CrossRef]

60. Mills, J.; Gaskell, P.; Ingram, J.; Dwyer, J.; Reed, M.; Short, C. Engaging farmers in environmental management through a better understanding of behaviour. Agric. Hum. Values 2017, 34, 283-299. [CrossRef]

61. Canova, M.A.; Lapola, D.M.; Pinho, P.; Dick, J.; Patricio, G.B.; Priess, J.A. Different ecosystem services, same (dis) satisfaction with compensation: A critical comparison between farmers' perception in Scotland and Brazil. Ecosyst. Serv. 2019, 35, 164-172. [CrossRef]

62. Liu, J.; Li, S.; Ouyang, Z.; Tam, C.; Chen, X. Ecological and socioeconomic effects of China's policies for ecosystem services. Proc. Natl. Acad. Sci. USA 2008, 105, 9477-9482. [CrossRef]

63. Su, S.; Wan, C.; Li, J.; Jin, X.; Pi, J.; Zhang, Q.; Weng, M. Economic benefit and ecological cost of enlarging tea cultivation in subtropical China: Characterizing the trade-off for policy implications. Land Use Policy 2017, 66, 183-195. [CrossRef]

64. Lai, Z.; Chen, M.; Liu, T. Changes in and prospects for cultivated land use since the reform and opening up in China. Land Use Policy 2020, 97, 104781. [CrossRef]

65. Franzen, A.; Vogl, D. Two decades of measuring environmental attitudes: A comparative analysis of 33 countries. Glob. Environ. Change 2013, 23, 1001-1008. [CrossRef]

66. Kong, F.; Xiong, K.; Zhang, N. Determinants of farmers' willingness to pay and its level for ecological compensation of Poyang Lake Wetland, China: A household-level survey. Sustainability 2014, 6, 6714-6728. [CrossRef]

67. Qi, X.; Wang, R.Y.; Li, J.; Zhang, T.; Liu, L.; He, Y. Ensuring food security with lower environmental costs under intensive agricultural land use patterns: A case study from China. J. Environ. Manag. 2018, 213, 329-340. [CrossRef] [PubMed]

68. Yang, X.; Sui, P.; Zhang, X.; Dai, H.; Yan, P.; Li, C.; Wang, X.; Chen, Y. Environmental and economic consequences analysis of cropping systems from fragmented to concentrated farmland in the North China Plain based on a joint use of life cycle assessment, emergy and economic analysis. J. Environ. Manag. 2019, 251, 109588. [CrossRef] [PubMed]

69. Bravol, G.; Marelli, B. Micro-foundations of the Environmental Kuznets Curve hypothesis: An empirical analysis. Int. J. Innov. Sustain. Dev. 2007, 2, 36-62. [CrossRef]

70. Poppenborg, P.; Koellner, T. Do attitudes toward ecosystem services determine agricultural land use practices? An analysis of farmers' decision-making in a South Korean watershed. Land Use Policy 2013, 31, 422-429. [CrossRef]

71. Leßmeister, A.; Heubach, K.; Lykke, A.M.; Thiombiano, A.; Wittig, R.; Hahn, K. The contribution of non-timber forest products (NTFPs) to rural household revenues in two villages in south-eastern Burkina Faso. Agrofor. Syst. 2018, 92, 139-155. [CrossRef]

72. Zhang, L.; Li, X.; Yu, J.; Yao, X. Toward cleaner production: What drives farmers to adopt eco-friendly agricultural production? J. Clean. Prod. 2018, 184, 550-558. [CrossRef]

73. Tam, K.-P.; Chan, H.-W. Environmental concern has a weaker association with pro-environmental behavior in some societies than others: A cross-cultural psychology perspective. J. Environ. Psychol. 2017, 53, 213-223. [CrossRef]

74. Tam, K.-P.; Chan, H.-W. Generalized trust narrows the gap between environmental concern and pro-environmental behavior: Multilevel evidence. Glob. Environ. Change 2018, 48, 182-194. [CrossRef]

75. Wang, Y.; Bilsborrow, R.E.; Zhang, Q.; Li, J.; Song, C. Effects of payment for ecosystem services and agricultural subsidy programs on rural household land use decisions in China: Synergy or trade-off? Land Use Policy 2019, 81, 785-801. [CrossRef] 
76. Ross, C.T. Sliding-scale environmental service payments and non-financial incentives: Results of a survey of landowner interest in Costa Rica. Ecol. Econ. 2016, 130, 252-262. [CrossRef]

77. Pagliacci, F.; Defrancesco, E.; Mozzato, D.; Bortolini, L.; Pezzuolo, A.; Pirotti, F.; Pisani, E.; Gatto, P. Drivers of farmers' adoption and continuation of climate-smart agricultural practices. A study from northeastern Italy. Sci. Total Environ. 2020, 710, 136345. [CrossRef] [PubMed]

78. Meyer, A. Does education increase pro-environmental behavior? Evidence from Europe. Ecol. Econ. 2015, 116, 108-121. [CrossRef]

79. Ren, C.; Liu, S.; van Grinsven, H.; Reis, S.; Jin, S.; Liu, H.; Gu, B. The impact of farm size on agricultural sustainability. J. Clean. Prod. 2019, 220, 357-367. [CrossRef]

Publisher's Note: MDPI stays neutral with regard to jurisdictional claims in published maps and institutional affiliations.

(C) 2020 by the authors. Licensee MDPI, Basel, Switzerland. This article is an open access article distributed under the terms and conditions of the Creative Commons Attribution (CC BY) license (http://creativecommons.org/licenses/by/4.0/). 